\title{
Diversity of microcrustacea (Crustacea: Branchiopoda) of Loktak Lake, a Ramsar site, Manipur, India
}

\author{
B.K. Sharma ${ }^{1}$ \& Sumita Sharma ${ }^{2}$
}

\author{
${ }^{1}$ Department of Zoology, North-Eastern Hill University, Permanent Campus, Umshing, Shillong, Meghalaya 793022, India \\ ${ }^{2}$ Eastern Regional Station, Zoological Survey of India, Fruit Gardens, Risa Colony, Shillong, Meghalaya 793003, India \\ Email: ${ }^{1}$ bksharma@ @ehu.ac.in; ${ }^{2}$ sumitazsi@ hotmail.com
}

\begin{abstract}
Microcrustacea of Loktak Lake (collected during Nov. 2002-Oct. 2004) reveal 57 species and show qualitative dominance of Cladocera (51 species). They indicate monthly richness ranging between $33 \pm 6$ and $32 \pm 6$ species, record $51.7-82.3$ and $53.6-90.0 \%$ community similarities during two years respectively, and follow trimodal annual patterns with peaks during winter. The microcrustaceans $(112 \pm 17$ and $124 \pm 13 \mathrm{n} / \mathrm{l})$ form an important quantitative component $(45.7 \pm 4.9$ and $43.3 \pm 3.7 \%)$ of zooplankton and show broadly trimodal annual patterns with peak abundance during winter. Cladocera > Copepoda mainly contribute to their quantitative variations. ANOVA registers significant monthly variations of microcrustacea richness and significant annual and monthly variations of their abundance. Richness is positively correlated with dissolved oxygen and is negatively correlated with rainfall, hardness, chloride and total dissolved solids while abundance is negatively correlated with $\mathrm{pH}$ only. Multiple regressions indicate higher cumulative effect of 15 abiotic factors on richness and abundance. Our results indicate no definite periodicity of richness and abundance of microcrustacea or their constituent groups during two annual cycles and are characterized by their higher species diversity, higher evenness and lower dominance.
\end{abstract}

Keywords: Abundance, dominance, ecology, equitability, Loktak Lake, microcrustacea, Ramsar site, richness, species diversity.

Date of publication (online): 26 November 2009 Date of publication (print): 26 November 2009 ISSN 0974-7907 (online) | 0974-7893 (print)

Editor: M.M. Saxena

Manuscript details:

Ms \# 02231

Received 08 June 2009

Finally accepted 03 November 2009

Citation: Sharma, B.K. \& S. Sharma (2009). Diversity of microcrustacea (Crustacea: Branchiopoda) of Loktak Lake, a Ramsar site, Manipur, India. Journal of Threatened Taxa 1(11): 541-548.

Copyright: () B.K. Sharma \& Sumita Sharma 2009. Creative Commons Attribution 3.0 Unported License. JoTT allows unrestricted use of this article in any medium for non-profit purposes, reproduction and distribution by providing adequate credit to the authors and the source of publication.

Author Details: Both the authors specialize in biodiversity and ecology of freshwater zooplankton and have made significant contributions in the fields of their expertise.

Author Contribution: The present study is the result of collaborative work undertaken by the authors, mainly at the research laboratory of the senior author.

Acknowledgments: This study formed a part of the "Potential for Excellence Program (Focused Area: Biosciences)" of North-Eastern Hill University, Shillong. The first author is thankful to G.B. Pant Institute of Himalayan Environmental Development, Almora for a research grant. Thanks are due to the Head, Department of Zoology, North-Eastern Hill University, Shillong for laboratory facilities. The second author is thankful to the Director, Zoological Survey of India, Kolkata.
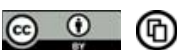

OPEN ACGESS | FREE DOWNLOAD

\section{INTRODUCTION}

Microcrustacea include various groups of brachiopod crustaceans which colonize the littoral and limnetic regions of different freshwater ecosystems. They comprise an integral link of aquatic food-web, form important component of metazooplankton and contribute notably to biological productivity in freshwaters. Though microcrustacea often form part of zooplankton studies from different parts of India, there are yet limited studies on their ecosystem diversity and role in aquatic productivity in freshwater environs of this country in general and the floodplain lakes in particular (Sharma \& Sharma 2009) because of inadequate community analysis and incomplete species inventories. The related information from the floodplains of northeastern India is so far limited to the works of Sharma \& Hussain (2001) and Sharma \& Sharma (2008, 2009).

The present study on microcrustacea of Loktak - a Ramsar site, an important floodplain lake of South Asia and one of the largest natural freshwater lakes of eastern India, assumes special limnological importance in view of the stated lacunae. The observations are made on qualitative and quantitative analysis of the microcrustacean communities of this wetland with special reference to their richness, community similarities, abundance, species diversity, evenness and dominance as well as their constituent groups during two years of the study period. In addition, the influence of abiotic parameters on their richness and abundance are analyzed to understand ecological correlations.

\section{Materials and Methods}

This study is a part of limnological survey undertaken (Nov. 2002 - Oct. 2004) in Loktak Lake $\left(93^{\circ} 46^{\prime}-93^{\circ} 55^{\prime} \mathrm{E} \& 4^{\circ} 25^{\prime}-24^{\circ} 42^{\prime} \mathrm{N}\right.$ ) located in Bishnupur / Imphal districts of Manipur (northeastern India). This floodplain lake is characterized by floating mats of vegetation called "phumdi" which are inhabited by the threatened Brow-antlered Deer (Rucervus eldii eldii). The common aquatic plants of this wetland include Eichhornia crassipes, Hydrilla verticellata, Euryale ferox, Vallisnaria spiralis, Utricularia flexuosa, Trapa natans, Lemna trisula, Pistia striates, Salvinia sp. Nymphaea spp., Nymphoides spp., Nelumbo mucifera, Potamageton spp. and Azolla pinnata.

The observations were undertaken at monthly intervals, during the study period, at one selected sampling site at Sendra $\left(93^{\circ} 47^{\prime} 45.61^{\prime \prime} \mathrm{E} \& 24^{\circ} 30^{\prime} 56.75^{\prime \prime} \mathrm{N}\right)$. Water samples collected were analyzed for various abiotic factors following APHA (1992) while water temperature, specific conductivity, $\mathrm{pH}$ and dissolved oxygen were recorded by the field probes. Qualitative (by towing) and quantitative (by filtering 251 water each) net plankton samples were collected by nylobolt plankton net (No. 25) and were preserved 
in $5 \%$ formalin. The former were screened and different species were identified following the works of Smirnov (1971, 1976, 1992, 1996), Michael \& Sharma (1988), Korovchinsky (1992), Sharma \& Sharma $(1999,2008)$ and Orlova-Bienkowskaja (2001). Quantitative samples were analyzed for abundance of Microcrustacea and their constituent groups using SedgwickRafter counting cell. Community similarities (Sorensen's index), species diversity (Shannon's index), dominance (BergerParker's index) and evenness (Pileou's index) were calculated following Ludwig \& Reynolds (1988) and Magurran (1988). Significance of temporal variations of biotic parameters was ascertained by ANOVA (two-way). Ecological correlations between abiotic and biotic parameters were determined by simple correlation coefficients $(\mathrm{r})$. Multiple regression $\left(\mathrm{R}^{2}\right)$ was used to ascertain cumulative effect of 15 abiotic factors (water temperature, rainfall, $\mathrm{pH}$, specific conductivity, dissolved oxygen, free carbon dioxide, alkalinity, hardness, phosphate, nitrate, sulphate, silicate, chloride, dissolved organic matter and total dissolved solids) on biotic factors.

\section{Results and Discussion}

\section{Abiotic parameters}

Mean water temperature affirms sub-tropical range of Loktak Lake. Specific conductivity indicates low ionic concentration (Table 1) and, hence, warrants inclusion of this Ramsar site under 'Class I' category of Talling \& Talling (1965). Slightly acidic and soft waters of this floodplain lake depict moderate dissolved $\mathrm{O}_{2}$, low free $\mathrm{CO}_{2}$, low concentration of micronutrients and other abiotic factors.

\section{Richness and community similarities}

Plankton samples examined from Loktak Lake reveal 57 species of microcrustacea, indicate highly speciose and diverse biocoenosis and, in turn, reflect greater environmental heterogeneity of this Ramsar site. The richness exceeds the highest Indian report of 51 species (Sharma \& Sharma 2009) known from Deepor beel - another Ramsar site and an important floodplain lake of northeastern India. All the examined species are observed during first year while 53 species are noticed during the succeeding year of the study period. Microcrustacea (Table 2) contribute notably ( $33 \pm 6,32 \pm 6$ species) to qualitative variations of zooplankton of Loktak Lake ( $r=$ $0.746)$. Their richness registers significant temporal differences between months $\left(\mathrm{F}_{11,23}=25.347, \mathrm{P}<0.005\right)$ but shows insignificant annual variations. It follows trimodal and broadly concurrent annual patterns (Fig. 1) with peaks during winter (December) and minima during monsoon (July). Qualitative importance of micro-crustaceans, their trimodal patterns and winter peaks correspond with the results of Deepor beel (Sharma \& Sharma 2009) while our results deviate from the later in their monsoon minima. Richness records significant negative correlations with rainfall $(r=-0.467)$, hardness $(r=-0.560)$, chloride $(r=-0.684)$ and total dissolved solids $(r=-0.552)$ and it is positively correlated with dissolved oxygen $(r=0.538)$. Multiple regression indicates higher cumulative effect of 15 abiotic factors on Microcrustacea richness $\left(\mathrm{R}^{2}=0.743\right)$.

Cladocera (51 species), main qualitative component, are represented by 51 and 47 species respectively during two years (Table 2). The present study indicates the richest diversity of
Table 1. Abiotic factors of Loktak Lake

\begin{tabular}{|c|c|c|c|}
\hline Parameters & $\begin{array}{l}2002-03 \\
\text { Mean } \pm \text { SD }\end{array}$ & $\begin{array}{l}2003-04 \\
\text { Mean } \pm \text { SD }\end{array}$ & $\begin{array}{l}\text { Study period } \\
\text { Mean } \pm \text { SD }\end{array}$ \\
\hline Water temperature ${ }^{\circ} \mathrm{C}$ & $21.4 \pm 4.0$ & $22.2 \pm 4.1$ & $21.8 \pm 4.2$ \\
\hline Rainfall mm & $112.1 \pm 116.8$ & $164.4 \pm 183.7$ & $138.2 \pm 154.8$ \\
\hline $\mathrm{pH}$ & $6.38 \pm 0.23$ & $6.25 \pm 0.39$ & $6.31 \pm 0.32$ \\
\hline Specific conductivity $\mu \mathrm{S} / \mathrm{cm}$ & $98.9 \pm 19.7$ & $87.9 \pm 11.1$ & $93.3 \pm 17.1$ \\
\hline Dissolved $\mathrm{O}_{2} \mathrm{mg} / \mathrm{l}$ & $6.2 \pm 1.1$ & $5.3 \pm 0.7$ & $5.7 \pm 1.1$ \\
\hline Free $\mathrm{CO}_{2} \mathrm{mg} / \mathrm{l}$ & $9.5 \pm 2.1$ & $8.9 \pm 2.0$ & $9.2 \pm 2.0$ \\
\hline Alkalinity $\mathrm{mg} / \mathrm{l}$ & $16.0 \pm 4.4$ & $22.1 \pm 8.1$ & $19.1 \pm 7.1$ \\
\hline Hardness mg/l & $38.1 \pm 8.2$ & $38.4 \pm 7.2$ & $38.3 \pm 7.8$ \\
\hline Phosphate mg/l & $0.23 \pm 0.12$ & $0.21 \pm 0.04$ & $0.22 \pm 0.10$ \\
\hline Nitrate mg/l & $0.34 \pm 0.04$ & $0.30 \pm 0.03$ & $0.32 \pm 0.04$ \\
\hline Sulphate $\mathrm{mg} / \mathrm{l}$ & $0.86 \pm 0.12$ & $0.87 \pm 0.12$ & $0.86 \pm 0.12$ \\
\hline Silica mg/l & $10.4 \pm 1.2$ & $9.7 \pm 1.6$ & $10.1 \pm 1.4$ \\
\hline Chloride $\mathrm{mg} / \mathrm{l}$ & $14.9 \pm 3.1$ & $16.6 \pm 2.7$ & $15.8 \pm 3.0$ \\
\hline Dissolved organic & $1.38 \pm 0.40$ & $1.29 \pm 0.39$ & $1.34 \pm 0.39$ \\
\hline Total dissolved solids $\mathrm{mg} / \mathrm{l}$ & $0.46 \pm 0.22$ & $0.43 \pm 0.17$ & $0.44 \pm 0.19$ \\
\hline
\end{tabular}

this group so far known from any floodplain lake, Ramsar site and any aquatic ecosystem of India. Their richness exceeds previous highest Indian record of 45 species from Deepor Beel, another Ramsar site (Sharma \& Sharma 2008). The cladoceran richness merits special biodiversity interest in context of a conservative estimate (Fernando \& Kanduru 1984; Sharma \& Michael 1987) of occurrence of up to 60-65 species of this group from tropical and subtropical parts of India. The present report shows a significant departure from only nine cladoceran species listed earlier from Loktak Lake (Singh 1991) while it is also higher than our report of 21-39 species known from 15 floodplain lakes of the Brahmaputra river basin (Sharma \& Sharma 2008). Monthly richness of Cladocera (29 5 and $28 \pm 5$ species) exhibits identical annual ranges and mean values and, follows trimodal annual patterns identical with that of Microcrustacea. Winter peaks of Loktak Cladocera concur with those of Deepor Beel (Sharma \& Sharma 2008). ANOVA registers significant temporal variations in richness between months $\left(\mathrm{F}_{11,2 s}=43.304, \mathrm{p}<0.005\right)$ but records insignificant annual variations. Cladocera richness is negatively correlated with water temperature $(\mathrm{r}=-0.512)$, rainfall $(\mathrm{r}=-0.562), \mathrm{pH}(\mathrm{r}$ $=-0.504)$, hardness $(\mathrm{r}=-0.658)$, nitrate $(\mathrm{r}=-0.564)$, chloride $(\mathrm{r}=-0.627)$ and total dissolved solids $(\mathrm{r}=-0.785)$ while it is positively correlated with dissolved oxygen $(r=0.443)$. Multiple regression registers moderately higher cumulative influence of 15 abiotic factors $\left(\mathrm{R}^{2}=0.703\right)$ on their richness.

Microcrustacea community similarities (Tables $3 \& 4$ ) range between $51.8-87.3 \%$ during first year but depict marginally higher range $(54.2-90.9 \%)$ in the following year; the stated variations, however, broadly concur with the results of Deepor beel (Sharma \& Sharma 2009). Higher values (70-80\%) are noticed in 53.0 and $40.9 \%$ instances while 31.8 and $33.3 \%$ instance indicated in the matrices record $60-70 \%$ similarity respectively during two years of the study period. The cluster analysis shows (Figs. $2 \& 3$ ) distinct variations in the patterns of monthly groupings, thereby, indicating notable differences in their faunal composition during two years. Higher closeness is noticed between of microcrustacea communities during November-December-October-September in general and between November-December (peak similarity) in particular during first year. On the other hand, the samples collected during March-July in general and during June and July in particular exhibit greater divergence in their composition during this year. Higher closeness is noticed between March- 


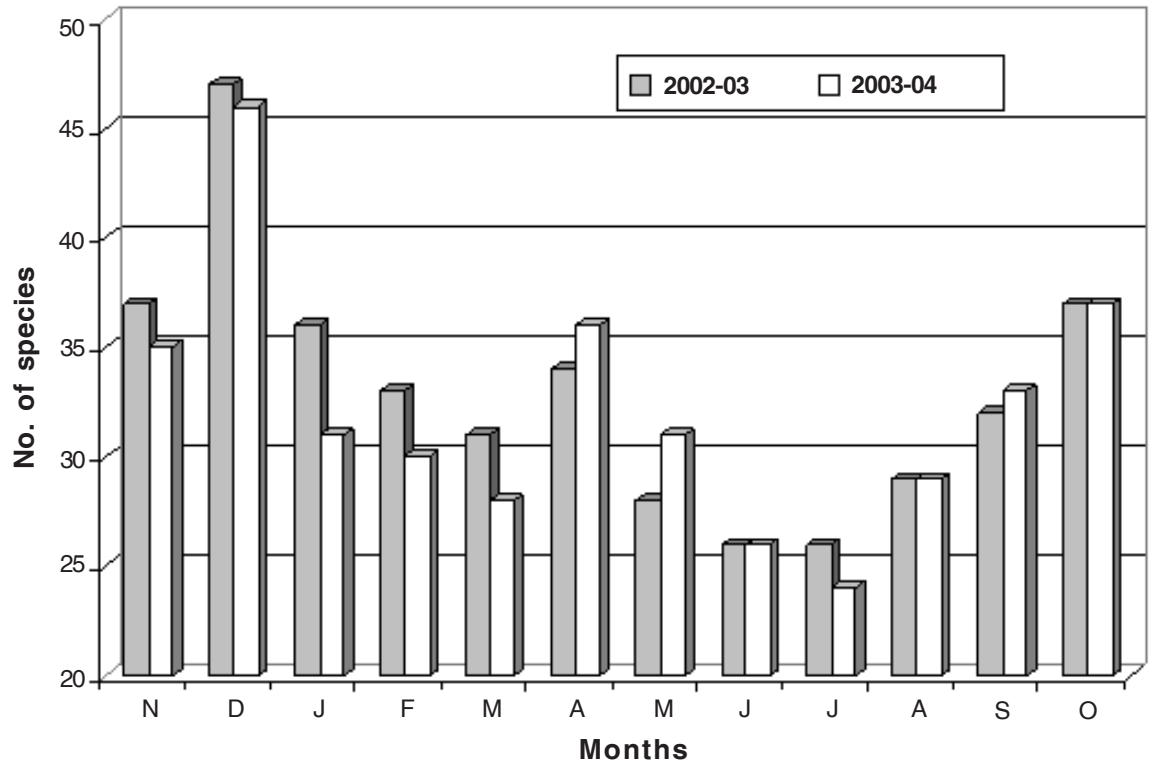

Rescaled Distance Cluster Combine

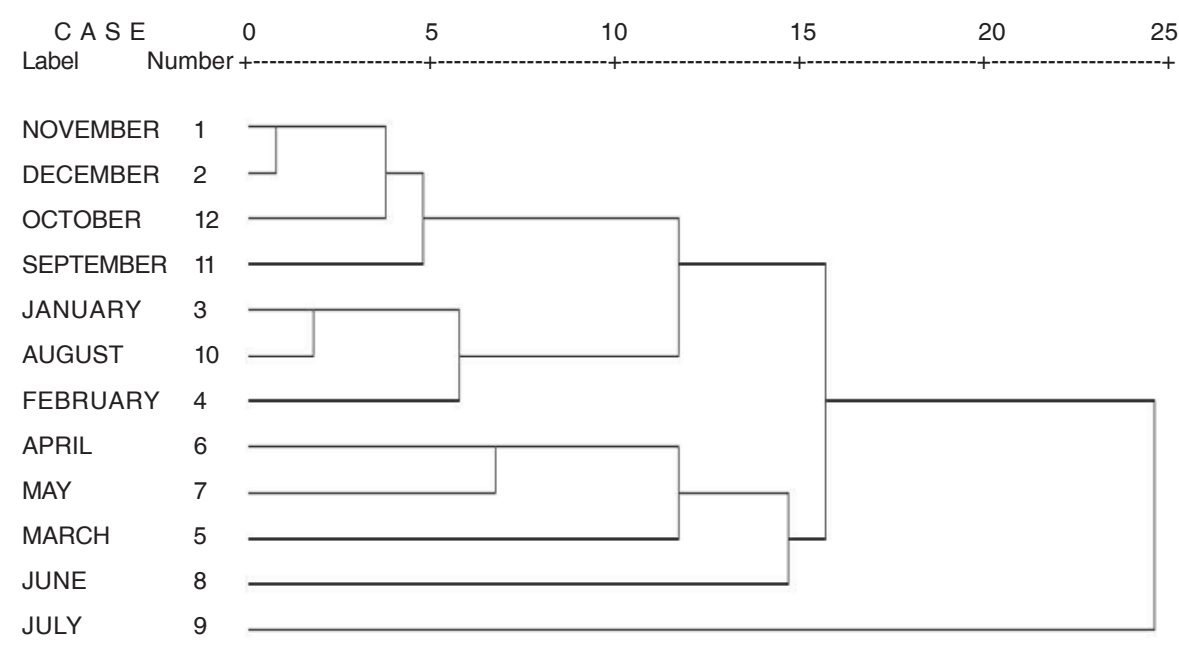

Rescaled Distance Cluster Combine

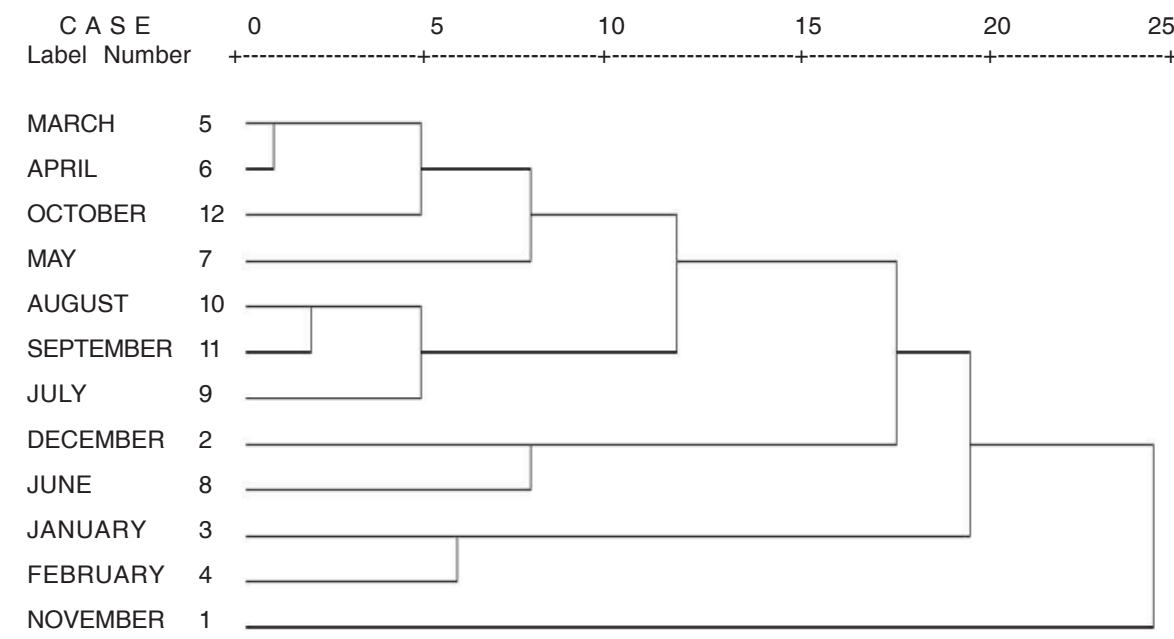

Figure 1. Monthly variations in richness in microcrustacea

Figure 2. Hierarchical cluster analysis of microcrustacea (2002-03)

Figure 3. Hierarchical cluster analysis of microcrustacea (2003-04) 
Table 2. Temporal variations of microcrustacea

\begin{tabular}{|c|c|c|}
\hline & 2002-03 & 2003-2004 \\
\hline $\begin{array}{l}\text { QUALITATIVE } \\
\text { Micro-Crustacea } 57 \text { species } \\
\text { Community similarity \% } \\
\text { Cladocera } 51 \text { species } \\
\text { Community similarity \% }\end{array}$ & $\begin{array}{l}26-47 \quad 33 \pm 6 \\
51.8-87.3 \\
22-42 \quad 29 \pm 5 \\
51.7-82.3\end{array}$ & $\begin{array}{l}24-46 \quad 32 \pm 6 \\
54.2-90.9 \\
20-41 \quad 28 \pm 5 \\
53.6-90.0\end{array}$ \\
\hline $\begin{array}{l}\text { QUANTITATIVE } \\
\text { Zooplankton (n/l) } \\
\text { Micro-Crustacea (n/l) } \\
\text { Percentage } \\
\text { Species Diversity } \\
\text { Evenness } \\
\text { Dominance }\end{array}$ & $\begin{array}{ll}204-319 & 246 \pm 35 \\
86-145 & 112 \pm 17 \\
39.8-54.7 & 45.7 \pm 4.9 \\
2.305-3.331 & 2.927 \pm 0.334 \\
0.746-0.983 & 0.883 \pm 0.077 \\
0.084-0.344 & 0.187 \pm 0.074\end{array}$ & $\begin{array}{ll}256-314 & 287 \pm 34 \\
108-154 & 124 \pm 13 \\
36.6-48.0 & 43.3 \pm 3.7 \\
2.615-3.526 & 2.904 \pm 0.246 \\
0.832-0.999 & 0.905 \pm 0.041 \\
0.111-0.193 & 0.155 \pm 0.023\end{array}$ \\
\hline $\begin{array}{l}\text { Different Groups } \\
\text { Cladocera (n/l) } \\
\text { Percentage } \\
\text { Species Diversity } \\
\text { Dominance } \\
\text { Evenness } \\
\text { Copepoda }(\mathrm{n} / \mathrm{l}) \\
\text { Percentage } \\
\text { Ostracoda (n/l) } \\
\text { Conchostraca }(\mathrm{n} / \mathrm{l})\end{array}$ & 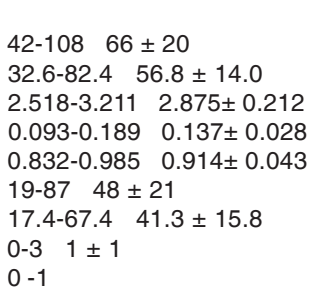 & $\begin{array}{ll}69-103 & 79 \pm 9 \\
51.1-771.7 & 64.7 \pm 7.3 \\
2.311-0.390 & 2.769 \pm 0.273 \\
0.093-0.189 & 0.137 \pm 0.028 \\
0.816-0.996 & 0.909 \pm 0.042 \\
26-64 & 44 \pm 11 \\
22.0-47.4 & 34.9 \pm 6.8 \\
0-2 & 1 \pm 1 \\
0-1 & \end{array}$ \\
\hline $\begin{array}{l}\text { Important families } \\
\text { Cladocera } \\
\text { Chydoridae }(\mathrm{n} / \mathrm{l}) \\
\text { Daphniidae }(\mathrm{n} / \mathrm{l}) \\
\text { Sidiidae }(\mathrm{n} / \mathrm{l})\end{array}$ & $\begin{array}{l}34 \pm 11 \\
14 \pm 6 \\
12 \pm 4\end{array}$ & $\begin{array}{l}39 \pm 7 \\
26 \pm 5 \\
11 \pm 3\end{array}$ \\
\hline $\begin{array}{l}\text { Copepoda } \\
\text { Cyclopidae (n/l) }\end{array}$ & $25 \pm 13$ & $23 \pm 7$ \\
\hline $\begin{array}{l}\text { Important species } \\
\text { Cladocera } \\
\text { Mesocyclops leuckarti (n/l) } \\
\text { Microcyclops hyalinus }(\mathrm{n} / \mathrm{l})\end{array}$ & $\begin{array}{l}17 \pm 11 \\
8 \pm 5\end{array}$ & $\begin{array}{l}16 \pm 8 \\
7 \pm 2\end{array}$ \\
\hline $\begin{array}{l}\text { Copepoda } \\
\text { Chydorus sphaericus (n/l) } \\
\text { Ceriodaphnia cornuta }(\mathrm{n} / \mathrm{l}) \\
\text { Scapholeberis kingi }(\mathrm{n} / \mathrm{l})\end{array}$ & $\begin{array}{l}7 \pm 5 \\
6 \pm 4 \\
6 \pm 3\end{array}$ & $\begin{array}{l}8 \pm 2 \\
10 \pm 5 \\
8 \pm 2\end{array}$ \\
\hline
\end{tabular}

April (peak similarity) and again between August-September in the following year while the samples collected during January, February and November exhibit distinct differences in their composition.

Microcrustacea (112 $\pm 17 \& 124 \pm 13 \mathrm{n} / \mathrm{l})$ form an important quantitative component $(45.7 \pm 4.9 \& 43.3 \pm 3.7 \%)$ of zooplankton during the study period. They register significant density variations between months $\left(\mathrm{F}_{11,23}=10.462, \mathrm{P}<0.005\right)$ as well as years $\left(\mathrm{F}_{1,23}=5.342, \mathrm{P}>0.005\right)$. Abundance exhibits trimodal annual patterns (Fig. 3 and 4), shows peaks during winter (December) but exhibits minima during monsoon (August $1^{\text {st }}$ year and September $2^{\text {nd }}$ year). It is negatively correlated with $\mathrm{pH}(\mathrm{r}=-0.544)$ only while multiple regression indicates significantly higher cumulative effect of 15 abiotic factors on their abundance $\left(\mathrm{R}^{2}=0.816\right)$. In general, lower abundance of the microcrustaceans of Loktak Lake and limited influence of abiotic factors are in contrast to the findings of Deepor beel (Sharma \& Sharma 2009).

Cladocera $(66 \pm 20 \& 79 \pm 9 \mathrm{n} / \mathrm{l})$ form dominant quantitative group (Table 2) of microcrustacea (56.8 $\pm 14.0 \& 64.7 \pm 7.3 \%$ ), register significant annual variations in abundance $\left(\mathrm{F}_{1,2 s}=\right.$ 7.927, $\mathrm{P}<0.02)$ and influence temporal variations of the latter $(\mathrm{r}=0.514)$. In addition, they form sub-dominant constituent (27.1 \pm 6.6 \& $27.8 \pm 18.4 \%)$ of zooplankton and also influence their density variations $(r=0.595)$ during the study period. The observed abundance is higher than the reports of Khan
(1987), Yadava et al. (1987), Baruah et al. (1993), Sinha et al. (1994), and Sharma \& Hussain (2001), while it is relatively lower than the results of Sanjer \& Sharma (1995), and Sharma \& Sharma (2009). Cladocera exhibit bimodal and multimodal patterns of quantitative variations respectively with annual peaks during winter (December) and summer minima (May) during both years. The recorded maxima and minima, however, concur with the results in Deepor Beel (Sharma \& Sharma 2009) but the former differ from summer maxima reported by Sanjer \& Sharma (1995), and Sharma \& Hussain (2001) while comparisons with other studies in the Indian floodplains are not possible because of lack of definite information. Cladocera abundance is negatively correlated with water temperature $(\mathrm{r}$ $=-0.467)$, hardness $(\mathrm{r}=-0.571)$, nitrate $(\mathrm{r}=-0.534)$, chloride $(\mathrm{r}=-0.421)$ and total dissolved solids $(\mathrm{r}=0.560)$. Multiple regression registers relatively lower cumulative effect of 15 abiotic factors on their abundance $\left(\mathrm{R}^{2}=0.696\right)$.

The cladocerans depict quantitative importance of the littoral-periphytonic / facultative planktonic species in general and members of the family Chydoridae (34 $\pm 11 \& 39 \pm 7 \mathrm{n} / \mathrm{l})$ in particular. This salient feature concurs with the results in Deepor Beel (Sharma \& Sharma 2009) while it is in contrast to lack of any such aspect noticed in several other Indian floodplain lakes (Khan 1987; Sanjer \& Sharma 1995; Sharma \& Hussain 2001; Khan 2003). The chydorids, however, show insignificant density variations between months as well as years. 
Table 3. Percentage similarities of microcrustacea (2002-03)

\begin{tabular}{|c|c|c|c|c|c|c|c|c|c|c|c|c|}
\hline Months & Nov & $\mathrm{Dec}$ & Jan & Feb & March & April & May & June & July & Aug & Sept & Oct \\
\hline Nov & - & 87.3 & 79.4 & 67.7 & 70.2 & 71.0 & 71.4 & 77.2 & 80.0 & 76.2 & 82.5 & 81.8 \\
\hline Dec & & - & 81.7 & 70.8 & 70.0 & 76.9 & 71.2 & 73.3 & 69.8 & 76.7 & 78.8 & 84.1 \\
\hline Jan & & & - & 80.6 & 70.2 & 67.7 & 67.9 & 67.7 & 70.0 & 82.5 & 76.2 & 78.8 \\
\hline Feb & & & & - & 74.5 & 64.3 & 64.0 & 72.7 & 70.4 & 77.2 & 73.7 & 66.7 \\
\hline March & & & & & - & 70.6 & 71.1 & 65.2 & 57.1 & 69.2 & 73.1 & 80.0 \\
\hline April & & & & & & - & 76.0 & 66.7 & 51.8 & 66.7 & 77.2 & 76.7 \\
\hline May & & & & & & & - & 75.6 & 58.3 & 66.7 & 70.6 & 74.1 \\
\hline June & & & & & & & & - & 69.4 & 65.4 & 69.2 & 76.4 \\
\hline July & & & & & & & & & - & 69.1 & 69.1 & 62.1 \\
\hline Aug & & & & & & & & & & - & 75.9 & 72.1 \\
\hline Sept & & & & & & & & & & & - & 78.7 \\
\hline Oct & & & & & & & & & & & & - \\
\hline
\end{tabular}

Table 4. Percentage similarities of microcrustacea (2003-04)

\begin{tabular}{|c|c|c|c|c|c|c|c|c|c|c|c|c|}
\hline Months & Nov & $\mathrm{Dec}$ & Jan & Feb & March & April & May & June & July & Aug & Sept & Oct \\
\hline Nov & - & 59.4 & 59.6 & 62.1 & 66.7 & 63.5 & 65.6 & 58.0 & 55.2 & 56.1 & 67.7 & 79.4 \\
\hline Dec & & - & 65.3 & 56.0 & 61.5 & 65.4 & 82.1 & 74.1 & 68.0 & 65.3 & 74.1 & 63.3 \\
\hline Jan & & & - & 79.1 & 57.8 & 54.2 & 65.3 & 72.3 & 69.8 & 76.2 & 76.6 & 67.9 \\
\hline Feb & & & & - & 69.6 & 61.2 & 56.0 & 66.7 & 73.8 & 72.7 & 75.0 & 74.1 \\
\hline March & & & & & - & 90.2 & 96.9 & 64.0 & 73.9 & 75.5 & 80.0 & 82.1 \\
\hline April & & & & & & - & 83.6 & 67.9 & 73.5 & 75.0 & 79.2 & 81.4 \\
\hline May & & & & & & & - & 74.1 & 72.0 & 69.4 & 81.5 & 76.7 \\
\hline June & & & & & & & & - & 79.2 & 68.1 & 73.1 & 65.5 \\
\hline July & & & & & & & & & - & 83.7 & 79.2 & 70.4 \\
\hline Aug & & & & & & & & & & - & 89.4 & 75.5 \\
\hline Sept & & & & & & & & & & & - & 79.3 \\
\hline Oct & & & & & & & & & & & & - \\
\hline
\end{tabular}
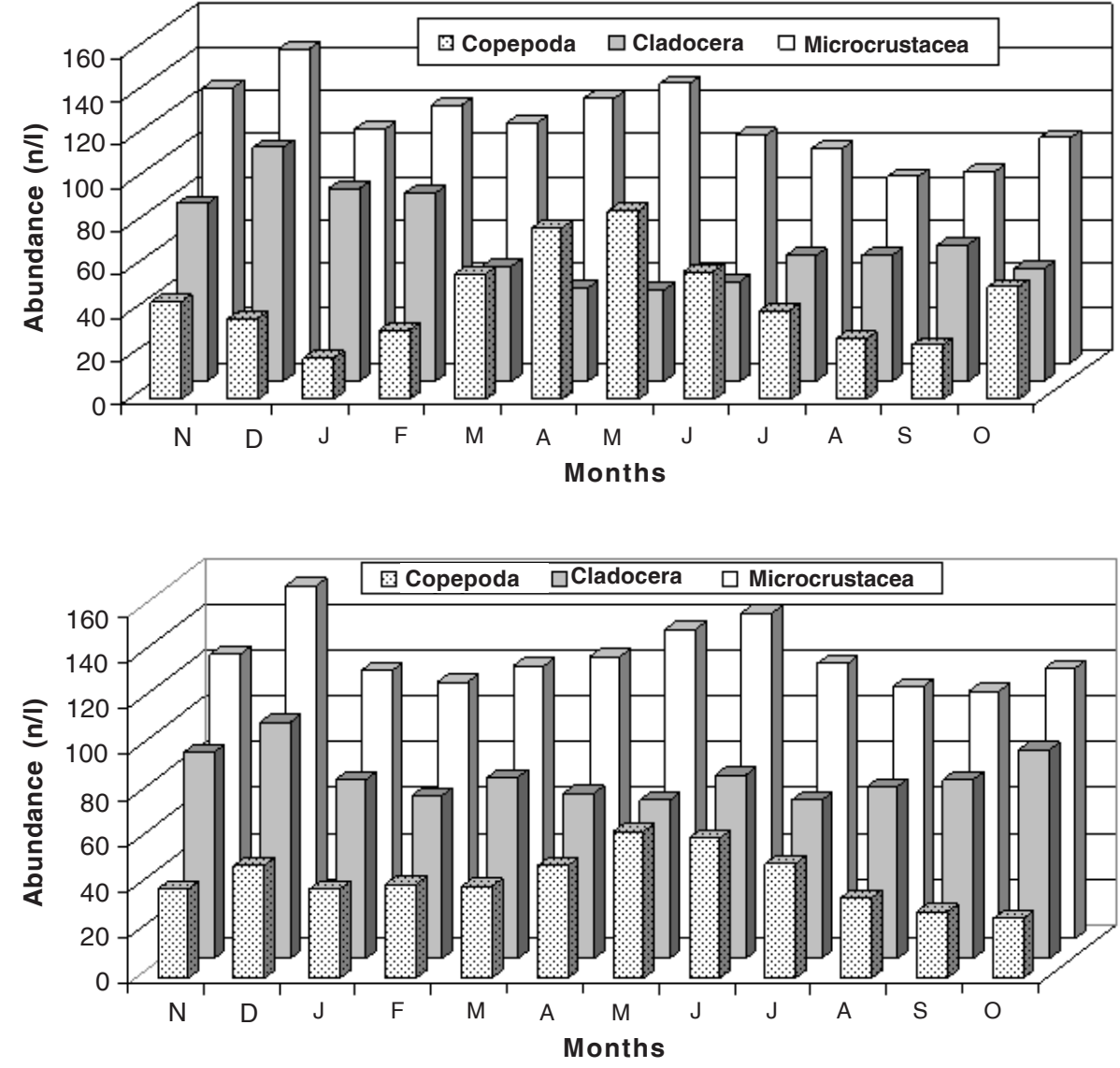

Figure 4. Abundance of Copepoda, Cladocera and microcrustacea (2002-03)

Figure 5. Abundance of Copepoda, Cladocera and microcrustacea (2003-04) 

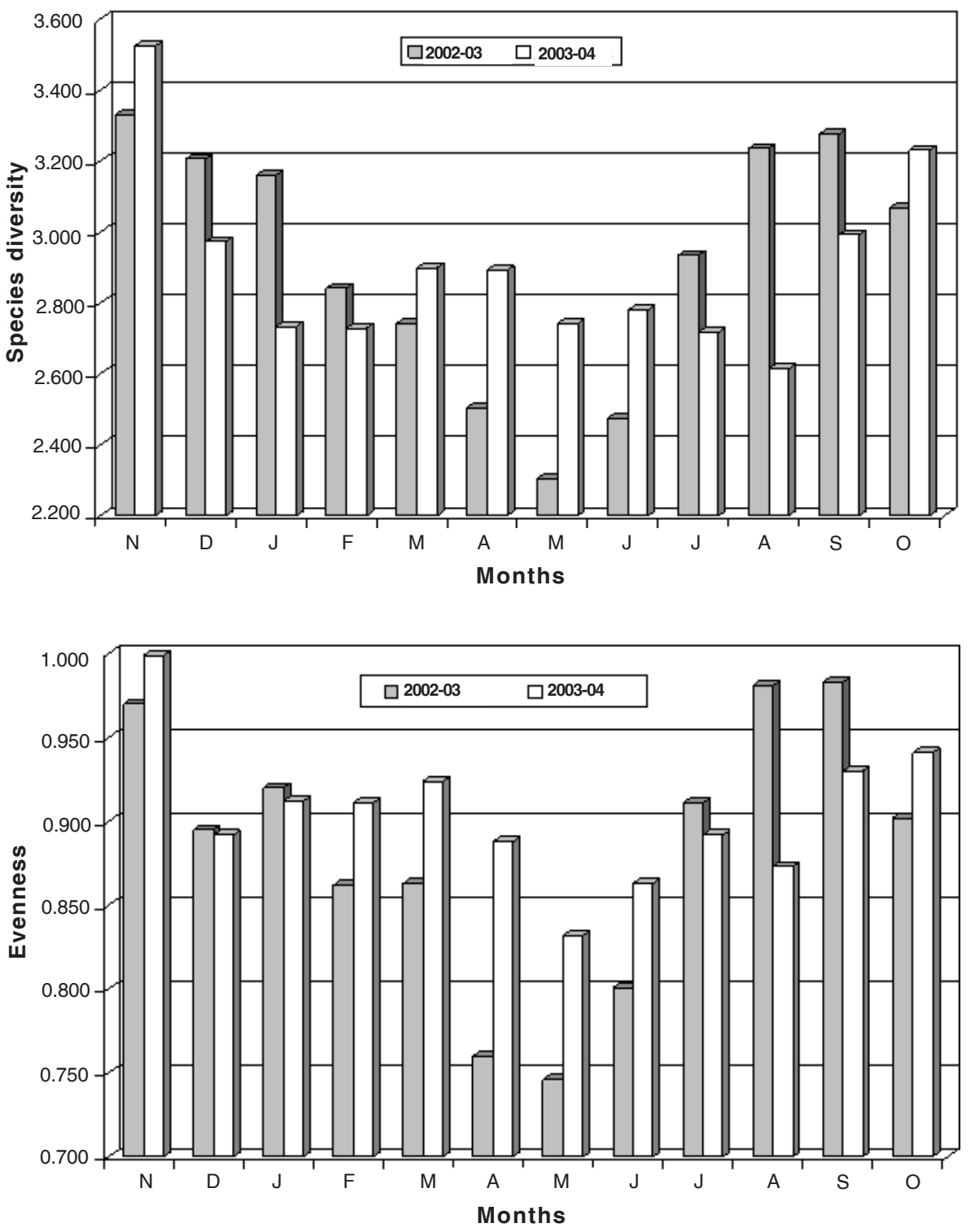

Figure 6. Monthly variations in species diversity of microcrustacea
Figure 7. Monthly variations in evenness of microcrustacea
They contribute significantly to abundance of Cladocera $(\mathrm{r}=$ 0.825 ) and also exhibit significant positive correlation with their richness $(r=0.637)$. They follow multimodal and trimodal patterns of temporal variations during two years respectively but show winter peaks (December) during both years. The chydorids register inverse correlations with hardness $(r=-$ $0.424)$, nitrate $(\mathrm{r}=-0.433)$ and total dissolved solids $(\mathrm{r}=-$ $0.430)$ in this study.

Daphniidae (14 16 \& $26 \pm 5 \mathrm{n} / \mathrm{l})$, another family of Cladocera, registers distinct quantitative variations between months $\left(\mathrm{F}_{11,23}=125.270, \mathrm{p}<0.005\right)$ as well as years $\left(\mathrm{F}_{1,23}=\right.$ 27.417, $\mathrm{p}<0.005)$. They follow trimodal annual patterns and record peak abundance during winter (December \& January) during both years; this trend is supported by their inverse correlation with water temperature $\left(r_{1}=-0.582\right)$. The Daphniidae exhibit inverse correlations with $\mathrm{pH}(\mathrm{r}=-0.419)$, free $\mathrm{CO}_{2}(\mathrm{r}=-0.542)$, hardness $(\mathrm{r}=-0.529)$, nitrate $(\mathrm{r}=-0.573)$ and total dissolved solids $(r=-0.481)$ in Loktak. Sidiidae, third notable family, record relatively lower abundance (12 44 $\& 11 \pm 3 \mathrm{n} / \mathrm{l}$ ) and register insignificant density variations between months and years during this study.
Copepoda $(48 \pm 21 \& 44 \pm 11 \mathrm{n} / \mathrm{l})$ form another important

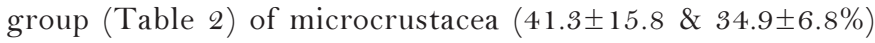
as well as sub-dominant component of zooplankton $(19.7 \pm 8.8$ \& $15.3 \pm 4.1 \%$ ) during both years respectively. The last feature is in contrast to their dominant role noticed by Yadava et al. (1987), Baruah et al. (1993), Sharma \& Hussain (2001), and Khan (2003). Their abundance in Loktak Lake, however, is lower than the reports of Khan (1987), Sinha et al. (1994), Sharma \& Hussain (2001), Khan (1987), Sharma \& Sharma (2009). The copepods exhibit trimodal patterns of temporal variations and show summer peaks (May) during both annual cycles; they register only significant monthly variations $\left(F_{11,23}\right.$ $=3.110, \mathrm{P}<0.05)$. The stated patterns differ from bimodal variations reported by Sharma \& Hussain (2001) but concur with the later with respect to higher densities during summer and monsoon seasons. Amongst the abiotic factors, Copepoda exhibit significant inverse relationship only with sodium $(r=$ -0.530) while multiple regression registers relatively lower cumulative effect of 15 abiotic factors on their abundance $\left(\mathrm{R}^{2}\right.$ $=0.723)$.

The Cyclopoida form main quantitative component of 


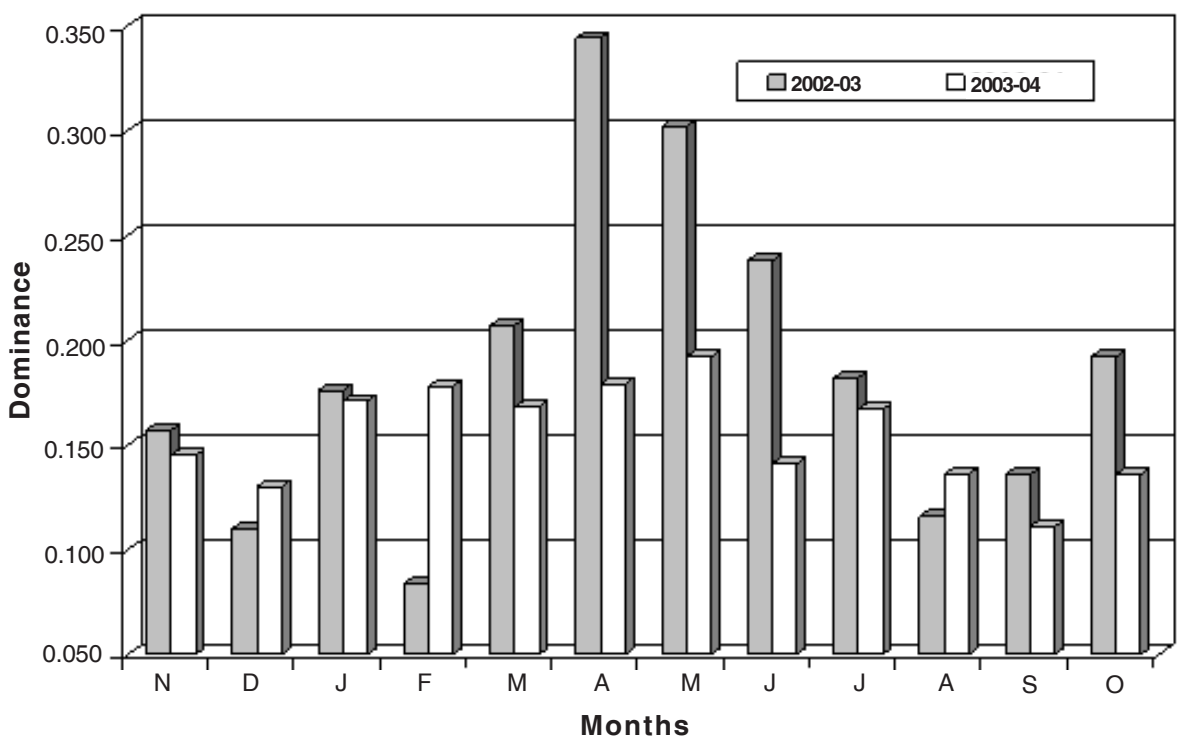

Figure 8. Monthly variations in dominance of microcrustacea
Copepoda; their dominance corresponds with earlier reports from the Indian floodplains by Khan (1987), Yadava et al (1987), Sanjer \& Sharma (1995), Sarma (2000), Sharma \& Hussain (2001), Khan (2003), and Sharma \& Sharma(2009). This generalization is also affirmed by lower abundance of Calanoidea, represented by Heliodiaptomus spp. Cyclopoida exhibit mean annual abundance of $26 \pm 12$ and $23 \pm 7 \mathrm{n} / \mathrm{l}$ respectively in Loktak and follow trimodal and bimodal patterns of quantitative variations which, in turn, are mainly influenced by Mesocyclops leuckarti $(17 \pm 11,16 \pm 8 \mathrm{n} / \mathrm{l})$. The occurrence of nauplii throughout the study period indicates an active continuous reproductive phase of the cyclopoid copepods as also reported earlier by Yadava et al (1987), Sharma \& Hussain (2001) and Sharma \& Sharma (2009).

\section{Species diversity, Evenness and Dominance}

The present results record wider variations but marginally different mean values of species diversity of microcrustacea

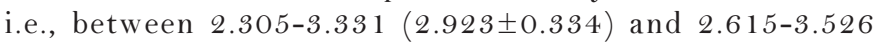
$(2.903 \pm 0.246)$ during two years respectively (Table 2). The diversity follows bimodal and trimodal annual patterns, shows peaks during autumn (November) during both annual cycles but indicates minima during summer (May) during first year and during monsoon (August) in the following year. Further, it registers insignificant temporal variations between months and years. Higher diversity values $(>3.0)$ are observed during November-February and again during August-October during first annual cycle while such values are noticed only during November and October in the succeeding annual cycle. The species diversity registers significant positive correlations with richness of microcrustacea $(r=0.501)$ and Cladocera $(r=0.448)$ as well as with abundance of Cladocera $(r=0.557)$ while it is negatively correlated with Copepoda abundance $(r=-0.689)$.

This study indicates (Table 2) higher microcrustacea evenness (0.746-0.983 \& 0.832-0.999) which registers significant temporal variations between months $\left(\mathrm{F}_{11,23}=3.033\right.$, $\mathrm{P}<0.05)$ and insignificant annual variations; the last aspect is also endorsed by marginal differences in mean values. Higher evenness reflects equitable abundance of various species. It follows (Fig. 8) trimodal and multimodal annual patterns with peaks during September and November respectively during two annual cycles while minima are recorded during summer (May) during both years of the study period. Evenness is positively correlated with species diversity of microcrustacea $(\mathrm{r}=0.884)$ and abundance of Cladocera $(\mathrm{r}=0.484)$ while it is negatively correlated with abundance of Copepoda $(r=-0.809)$.

Our results indicate (Table 2) lower dominance of microcrustacea (0.083-0.344 \& 0.111-0.193) which follows multimodal annual patterns during both years and registers insignificant monthly and annual variations. In general, lower dominance confirms lack of quantitative importance of individual species while it records marginally higher values during March-June during first years of the study period. Dominance is negatively correlated with species diversity $(\mathrm{r}=$ $-0.625)$ and evenness $(r=-0.716)$ and abundance $(r=-0.727)$ of Cladocera while it is positively correlated with Copepoda abundance $(r=0.793)$.

The stated features are endorsed (Table 2 ) by higher species diversity (2.875 $\pm 0.212 \& 2.904 \pm 0.273)$, higher evenness $(0.914 \pm 0.043 \& 0.909 \pm 0.042)$ and lower dominance $(0.137 \pm 0.028 \& 0.147 \pm 0.048)$ of Cladocera. These generalizations concur with the results of Sharma and Sharma (2009). These parameters follow multimodal patterns of temporal periodicity during both years and register insignificant monthly as well as annual variations during this study. Higher evenness and lower dominance of Cladocera affirm lower densities and equitable abundance of majority of species of this important qualitative and quantitative group of microcrustacea. The cladoceran species diversity registers significant direct correlation with their richness $(r=0.865)$; dominance registers inverse correlations with richness $(r=-$ $0.450)$ and species diversity $(r=-0.492)$ while evenness registers a positive correlation with diversity $(r=0.726)$ and an inverse relationship with dominance $(\mathrm{r}=-0.446)$.

To sum up, microcrustacea of Loktak Lake reflect rich and diverse biocoenosis; exhibit lack of definite periodicity of their richness or abundance or of their constituent groups; indicate lower densities of majority of species and lack of distinct quantitative importance of any individual species. Both microcrustacea and Cladocera are characterized by higher species diversity, higher evenness and lower dominance. Abiotic parameters influence on their richness and exhibit 
limited influence on their abundance but fifteen abiotic factors exert significant cumulative influence on these two communities.

\section{References}

APHA (1992). Standard Methods for the Examination of Water and Wastewater (18 $8^{\text {th }}$ ed.). American Public Health Association, Washington D.C.

Baruah, A., A.K. Sinha \& U.P. Sharma (1993). Plankton variability of a tropical wetland, Kawar (Begusarai), Bihar. Journal of Freshwater Biology 5: 27-32.

Fernando, C.H. \& A. Kanduru (1984). Some remarks on the latitudinal distribution of Cladocera on the Indian subcontinent. Hydrobiologia 113: $69-76$.

Khan, M.A. (1987). Observations on Zooplankton composition, abundance and periodicity in two flood plain lakes of the Kashmir Himalayan valley Acta Hydrochemica Hydrobiologia 15: 167-174.

Khan, R.A. (2002). The ecology and faunal diversity of two floodplain Ox-bow lakes of South-Eastern West Bengal. Records of the Zoological Survey of India, Occasional Paper No. 195: 1-57.

Khan, R.A. (2003). Faunal diversity of zooplankton in freshwater wetlands of Southeastern West Bengal. Records of the Zoological Survey of India, Occasional Paper No. 204: 1-107.

Korovchinsky, N.M. (1992). Sididae and Holopedidae. In: Guides to the Identification of the Microinvertebrates of the Continental Waters of the World. Vol. 3. SPB Academic Publishers. The Hague, 82pp.

Ludwig, J.A. \& J.F. Reynolds (1988). Statistical Ecology: A Primer on Methods and Computing. John Wiley \& Sons, New York, 337pp.

Magurran, A.E. (1988). Ecological Diversity and Its Measurement. Croom Helm Limited, London, 179pp.

Michael, R.G. \& B.K. Sharma (1988). Indian Cladocera (Crustacea: Branchiopoda: Cladocera). Fauna of India and adjacent countries Series. Published by Zoological Survey of India, Calcutta.

Orlova-Bienkowskaja, M.Y. (2001). Cladocera: Anomopoda. Daphniidae: Genus Simocephalus. In: Guides to the Identification of the Microinvertebrates of the Continental Waters of the World. Vol. 17. Backhuys Publishers, Leiden, the Netherlands, 130pp.

Sarma, P.K. (2000). Systematics, distribution and ecology of zooplankton of some floodplain wetlands of Assam, India. PhD thesis, Gauhati University, Assam.

Sanjer, L.R. \& U.P. Sharma (1995). Community structure of plankton in Kawar lake wetland, Begusarai, Bihar: II Zooplankton. Journal of Freshwater Biology 7: 165167.

Sharma, B.K. \& Md. Hussain (2001). Abundance and ecology of zooplankton in a tropical floodplain lake, Assam (N.E. India). Ecology, Environment \& Conservation 7(4): 397-403.
Sharma, B.K. \& R.G. Michael (1987). Review of taxonomic studies on freshwater cladocera from India with remarks on biogeography. Hydrobiologia 145: 29-33.

Sharma, B.K. \& S. Sharma (1999). Freshwater Cladocerans (Crustacea: Branchiopoda: Cladocera), pp. 469-550. In: Fauna of Meghalaya; State Fauna Series 4(9). Published by Zoological Survey of India, Calcutta

Sharma, B.K. \& S. Sharma (2008). Faunal diversity of Cladocera (Crustacea: Branchiopoda) of Deepor beel, Assam (Northeast India) - A Ramsar site. Journal of the Bombay Natural History Society 105(2): 196-201.

Sharma, B.K. \& S. Sharma (2009). Microcrustacea (Crustacea: Branchiopoda) of Deepor Beel, Assam, India: richness, abundance and ecology. Journal of Threatened Taxa 1(8): 411-418.

Sharma, S. \& B.K. Sharma (2008). Zooplankton diversity in floodplain lakes of Assam. Records of the Zoological Survey of India, Occasional Paper No. 290: 1-307.

Singh R.K.S. (1991). Study of nutrient enrichment in Loktak lake with reference to Biological indices. PhD Thesis, Manipur University, Manipur.

Sinha, A.K., A. Baruah, D.K. Singh \& U.P. Sharma (1994). Biodiversity and pollution status in relation to physico-chemical factors of Kawar lake (Begusarai), North Bihar. Journal of Freshwater Biology 6: 309331.

Smirnov, N.N. (1971). The World Chydorid Fauna (in Russian). USSR Acad. Sci. Zool. Inst. Nova series 101, Leningrad, 539pp.

Smirnov, N.N. (1976). The World Macrothricidae (in Russian). USSR Acad. Sci. Zool. Inst. Nova series 104, Leningrad, $112 \mathrm{pp}$.

Smirnov, N.N. (1992). The Macrothricidae of the world. In: Guides to the Identification of the Microinvertebrates of the Continental Waters of the World. Vol. 1. SPB Academic Publishers, the Hague, 143 pp.

Smirnov, N.N. (1996). Cladocera: the Chydorinae and Sayciinae (Chydoridae) of the world. In: Guides to the Identification of the Microinvertebrates of the Continental Waters of the World. Vol. 11. SPB Academic Publishers, The Hague, 197pp.

Talling. J.F. \& I.B. Talling (1965). The chemical composition of African lake waters. Internationale Revue gesammten Hydrobiologie 50: 421463 .

Yadava, Y.S., R.K. Singh, M. Choudhury \& V. Kolekar (1987). Limnology and productivity in Dighali beel (Assam). Tropical Ecology 28: $137-146$ 